\title{
VALIDITY AND RELIABILITY TEST OF MEDICATION ADHERENCE RATING SCALE FOR PSYCHOSIS (MARS) INSTRUMENT INDONESIAN VERSION
}

\author{
${\text { Kasmianto } \text { Abadi }^{1 *} \text {, A.A.A.A Kusumawardhani }}^{1}$, Natalia Widiasih ${ }^{1}$ and Khamelia \\ Malik $^{1}$ \\ ${ }^{1}$ Department of Psychiatry University Indonesia - Cipto Mangunkusumo National Referral Hospital, Indonesia
}

\begin{abstract}
Assessment of medication adherence is an important part of pharmacological treatment of psychotic disorders. This study aims to obtain a valid and reliable instrument to assess medication adherence in psychotic patients. This is a cross-sectional study conducted in the Psychiatric Outpatient Clinic of Cipto Mangunkusumo Hospital from January to July 2017. Subjects were recruited through consecutive sampling $(\mathrm{n}=100$, aged 18-59 years old). Psychotic disorders were diagnosed using Structured Clinical Interview and Diagnosis DSM-IV. The instrument was translated, adapted to Indonesian culture, and back-translated. Content validity and test-retest reliability ( $\mathrm{n}=35$ using systematic sampling) of MARS Indonesian version were evaluated. All items in the instrument are relevant to theory, as showed by content validity coefficient of 0.90 . Construct validity test showed that the items represent theoretical as well as conceptual construction of medication adherence. Internal consistency reliability was good, with Cronbach's alpha of 0.80 and 0.798 in the test-retest evaluation. This study produced a valid and reliable MARS Indonesian version. Currently there is no other instrument assessing medication adherence in psychotic patients in Indonesia.
\end{abstract}

Keywords: medication adherence rating scale, psychosis, reliability, validity

\section{Introduction}

The World Health Organization in 2001 estimated 450 million people worldwide suffered from mental illness, as well as about $10 \%$ of adults suffering from mental disorders today and $25 \%$ of the population is expected to experience mental disorders during their lifetime. This disorder generally occurs to young adults aged 18-21 years. According to the National Institute of Mental Health, mental disorders account for $13 \%$ of the overall disease and are expected to increase to $25 \%$ by 2030 . The incidence will contribute to the increasing prevalence of mental disorders in different countries (World Health Organization, 2011, World Health Organization, 2016, Rössler, et al., 2005). According to Indonesia Ministry of Health Research in 2013 the highest prevalence of mental disorders in Indonesia is found in Yogyakarta and Aceh Provinces of 2.7 per mil each, while the lowest in West Kalimantan are 0.7 per mil. The prevalence of severe national mental disorder is 1.7 per mil. The prevalence of severe psychiatric disorders in Indonesia is 0.3 to $1 \%$ and usually occurs between 18 and 45 years. Psychosis is a mental disorder characterized by distortions of thoughts, feelings, ability to judge reality and the ability to communicate with others (Sadock and Sadock, 2009).

Psychosis includes schizophrenia, schizophrenia-like disorder, schizoaffective disorder, delusional disorders, severe depression with psychotic symptoms, and bipolar affective disorder with psychotic symptoms (American Psychiatric Association, 2005). Noncompliance with medication becomes a problem of / with the management of psychotic patients, resulting in the frequent recurrence of re-hospitalization, prolonged hospitalization, shortened non-hospitalization time and worsening morbidity (Lacro, et al., 2002). Non-adherence to psychotherapy patients based on meta-analysis studies are 20-50\% (Kane and Kishimoto, 2013). This disobedience resulted in patients resistant to the drugs given, requiring higher doses of drugs or drug 
replacement, and causing relapses in $80 \%$ cases within the first two years after discontinuation of the drug (NIMH, 2016). Noncompliance may also result in longer hospital admissions and shorten the nonhospitalization time, which in turn will increase the burden of medical expenses. The support of the family or friends as well as the immediate environment is required for the patient to adhere to treatment (Rössler, et al., 2005).

Given that poor adherence is a problem that needs attention on the management of psychosis, it is necessary for clinicians to detect non-adherence problems in taking antipsychotic medications. Medication Adherence Rating Scale (MARS) is one of the measuring tools which, according to the research has good validity and reliability to measure the compliance of psychotic patients in taking medication. MARS has now been used in several countries, including Australia, United States of America, United Kingdom, Portugal, and France (Fond, et al., 2016, Zemmour, et al., 2016, Thompson, et al., 2000, Cohen and Swerdlik, 2005). Currently in Indonesia, especially in the Department of Psychiatry Faculty of Medicine University of Indonesia, Cipto Mangunkusumo Hospital does not yet have a valid and reliable instrument for measuring medication adherence in psychotic patients, therefore investigators aim to test the validity and reliability of MARS Indonesian version.

\section{Methods}

The samples were recruited based on inclusion and exclusion criteria.

Inclusion criteria:

1. Psychotic patient respondents were assessed with Structured Clinical Interview For DSM (SCID);

2. Respondents aged more than 18 to 59 years of age group;

3. Respondents are psychotic patients in a cooperative state for testing;

4. Respondents can understand the Indonesian language well with the parameters of education level graduated from Junior High School (Junior High School);

5. Respondents can read and write;

6. Respondents were conscious and able to focus, maintain, and divert adequately with Glasgow Coma Scale (GCS) examination;

7. Respondents were willing to be a respondent and fill out informed consent.

Exclusion criteria:

1. Subjects with mental retardation, which data were obtained from medical record information;

2. Subjects with impaired central organic nervous system, history of head trauma, and substance abuse, data obtained from medical records.

\section{Results}

Translation of the Medication Adherence Rating Scale instrument was performed by two translators who never seen or known this instrument. Translated results were then discussed by a group that consisted of the researcher and Mental Health experts. In the process of discussion, there were some questions that are considered difficult to be understood by the samples, for example question number 9. The initial translation of question number 9 reads "I feel strange, like the zombiw, when taking medicine". This statement was considered confusing because the majority of Indonesians are not familiar with the words "zombie." The discussion then agreed to replace the words "zombie" with "robot." The results of the discussion were then back translated and sent to the original authors of the MARS instruments, who are Kathrine Thompson, Jayashri Kulkarni, Alex A. Sergejew of the University of Melbourne, and they finally approved the adaptation (Thompson, et al., 2000). 


\section{The process of translation translation (Back translation) Instruments into English}

The translations in Indonesian were translated back to English by two different bilingual translators, who had not previously known about the MARS instrument. The results were then compared with the original version. This was done in order to see whether there was any significant differences in the items of the instrument's questions. The results of the reverse translation were sent to the instrument creator of MARS for approval.

\section{Process of Testing Instruments}

The trial process of MARS Indonesian version was performed on 10 samples. The samples were the patients of Psychiatry Outpatient Clinic in Cipto Mangunkusumo Hospital.

\section{Test Validity and Reliability}

The validity test of MARS Indonesian version was tested in a sample of 100 people, based on the instrument validity test recommendations that stated that samples could range from 30-500 samples. To test the reliability of MARS instrument, the researcher used a sample of 35 people based on the calculation of minimum sample with correlation coefficient of 0.5 at $95 \%$ degree of confidence and $80 \%$ power, with a result of 29 people.

\section{Demographic Characteristics of Research Subjects}

Table 1 described the demographic characteristics of the samples of this study. The samples had an average age of 31.3 years with age range of 18 to 55 years. Based on the normality test using Kolmogorov-Smirnov test, it was known that the sample had a $\mathrm{p}$ value of 0.006 which indicated that the data was not normally distributed. A total of 62 samples was male while the other 38 samples were female. The sample had a diverse level of education with the highest distribution was high school education level of 56 people. Data on marital status indicated that 87 samples were married while 13 were not married at the time of the study. Data on employment indicated that the majority sample did not have a job (49 people). The majority of samples' diagnosis in this study was schizophrenia (64 people). Throughout the course of the study, no patients were excluded; all samples filled out the questionnaire completely.

Table 1 Demographic Characteristics of the Samples $(n=100)$.

\begin{tabular}{llll}
\hline Characterisstic & & Median & Min-Max \\
\hline Age & & 30 & $18-55$ \\
\hline Sex & Male & 62 & 62 \\
\hline Education & Female & 38 & 38 \\
\hline & Primary School & 4 & 4 \\
\hline & Secondary High School & 20 & 20 \\
\hline & Senior High School & 56 & 56 \\
\hline & Mechanical School & 1 & 1 \\
\hline & Diploma & 4 & 4 \\
\hline Marital Status & Undergraduate & 9 & 9 \\
\hline & Postgraduate & 6 & 6 \\
\hline Pekerjaan & Married & 87 & 87 \\
\hline & Unmarried & 13 & 13 \\
\hline
\end{tabular}




\begin{tabular}{llll}
\hline & Housewife & 5 & 5 \\
\hline & Worker & 15 & 15 \\
\hline & Farmer & 2 & 2 \\
& Entrepeneur & 25 & 25 \\
\hline Diagnosis & Unemployed & 49 & 49 \\
\hline & Bipolar & 2 & 2 \\
\hline & Depression & 10 & 10 \\
\hline & Acute Psychosis & 4 & 4 \\
\hline & Schizoaffective & 20 & 20 \\
\hline Schizophrenia & 64 & 64 \\
\hline
\end{tabular}

\section{Internal Consistency Reliability Test}

The internal consistency reliability of the MARS Indonesian version was determined by calculating the value of Cronbach's Alpha. The value of Cronbach's Alpha was calculated for every instrument subscale.

Table 2 Internal Consistency Reliability of the Medication Adherence Rating Scale Indonesian version, First

Test.

\begin{tabular}{llll}
\hline & Scale Mean if Item Deleted & Scale Variance if Item Deleted & Cronbach's Alpha if Item Deleted \\
\hline $\mathrm{q} 1$ & 3.9100 & 5.962 & .704 \\
\hline $\mathrm{q} 2$ & 4.1900 & 5.085 & .740 \\
\hline $\mathrm{q} 3$ & 4.1800 & 5.644 & .779 \\
\hline $\mathrm{q} 4$ & 4.3400 & 6.368 & .803 \\
\hline $\mathrm{q} 5$ & 4.1900 & 5.085 & .740 \\
\hline $\mathrm{q} 6$ & 4.1800 & 5.644 & .779 \\
\hline $\mathrm{q} 7$ & 3.6200 & 6.097 & .788 \\
\hline $\mathrm{q} 8$ & 3.7600 & 5.477 & .767 \\
\hline $\mathrm{q} 10$ & 4.1900 & 6.043 & .701 \\
\hline
\end{tabular}

Table 3 Internal Consistency Reliability of the Medication Adherence Rating Scale Indonesian version, Second Test.

\begin{tabular}{llll}
\hline & Scale Mean if Item Deleted & Scale Variance if Item Deleted & Cronbach's Alpha if Item Deleted \\
\hline $\mathrm{q} 1$ & 3.8100 & 5.754 & .711 \\
\hline $\mathrm{q} 2$ & 4.1690 & 5.075 & .740 \\
\hline $\mathrm{q} 3$ & 4.1950 & 5.654 & .779 \\
\hline $\mathrm{q} 4$ & 4.3430 & 6.388 & .798 \\
\hline $\mathrm{q} 5$ & 4.2960 & 5.055 & .740 \\
\hline $\mathrm{q} 6$ & 4.3800 & 5.654 & .779 \\
\hline $\mathrm{q} 7$ & 3.6700 & 6.077 & .788 \\
\hline $\mathrm{q} 8$ & 3.7700 & 5.372 & .767 \\
\hline $\mathrm{q} 9$ & 3.7900 & 6.042 & .701 \\
\hline $\mathrm{q} 10$ & 4.1800 & 6.316 & .712 \\
\hline
\end{tabular}




\section{Content Validity Test}

Testing the content validity was done based on the assessment by two Mental Health experts. Each of the experts gave an qualitative assessment for each statement on the MARS Indonesian version, using a scale of 1 to 4, i.e. 1 (irrelevant) scale, 2 (somewhat relevant), 3 (quite relevant), and 4 (very relevant). After the assessment was completed, the data was processed in a $2 \times 2$ table.

Based on the $2 \times 2$ table above, it was deduced that the content validity coefficient for the MARS Indonesian version was 0.9 . The formula produced values that range from +1 to -1 , positive values indicate that at least half the value of valuing items as important/essential. The larger the Content Validity Ratio (CVR), the more "important" and the higher the validity of the content. The CVR value obtained in this study was 0.9 , which indicated that the items used has good content validity (Zygmunt, et al., 2002).

\section{Construction Validity Test Using Factor Analysis Method}

Factor analysis was performed to know the factors that make up the MARS Indonesian version. Prior to performing factor analysis, it was ensured that the requirements for performing factor analysis were fulfilled. The first requirement was the inter-item correlation value ranging from 0.07 to 0.72 . These results indicated that there was no strong correlation between items which showed multicollinearity. The Kaiser-Meyer-Olkin Test Measure of Sampling Adequacy gave a value of 0.896 indicating that the sample was adequate for factor analysis. Bartlett's Test of Sphericity gives $\mathrm{P}<0.01$ which indicated the correlation matrix was not an identity matrix. Based on these results, it was known that the requirements for performing factor analysis were fullfilled.

Table 4 Determination of adequate sampling by Kaiser-Meyer-Olkin Test and Bartlett's Test.

\begin{tabular}{lll}
\hline Kaiser-Meyer-Olkin Measure of Sampling Adequacy & & .896 \\
\hline Bartlett's Test of Sphericity & Approx. Chi-Square & 1360.654 \\
\hline & Df & 99 \\
\hline
\end{tabular}

Factor analysis was done by using Principal Component Analysis method which extracted four factors. The method is used to determine the minimum number of factors that play a role in achieving maximum variance in the data. This method can also be used to reduce data. The method used in this research is Varimax rotation method with Kaiser Normalization. Based on preliminary research conducted by Kathrine et al, it is known there were 4 factors that made up the MARS instrument. These factors included attitude towards treatment, behavior towards treatment, antipsychotic side effects, and attitude toward antipsychotic treatment.

Table 5 Factor Analysis of MARS Indonesian Version Using Varimax Rotation Method.

\begin{tabular}{lllll}
\hline Item No. & Factor & & \\
\hline & 1 & 2 & 3 & 4 \\
\hline Q2 & .896 & .259 & .056 & .065 \\
\hline Q3 & .870 & .261 & .086 & .148 \\
\hline Q1 & .730 & -.076 & -.082 & .006 \\
\hline Q5 & .724 & .579 & .338 & .147 \\
\hline Q6 & .110 & .871 & .039 & .238 \\
\hline Q8 & .000 & .864 & .220 & .189 \\
\hline
\end{tabular}


Proceeding of the $4^{\text {th }}$ International Conference on Public Health, Vol. 4, 2018, pp. 79-87

\begin{tabular}{lllll}
\hline Q7 & .047 & .863 & -.052 & .045 \\
\hline Q9 & .080 & .234 & .861 & .019 \\
\hline Q10 & .171 & .226 & .060 & .877 \\
\hline
\end{tabular}

Based on the matrix above, the researcher obtained the composition of statements in the Indonesian version of MARS that could be divided into the following four factors:

- Factor 1, including item number 1, 2, 3, and 4. The division of those four items to the attitude toward treatment subscale was in accordance with the original version of MARS.

- Factor 2, including items 5, 6, 7, and 8. The division the four items to the behavior towards medication subscale was in accordance with the original version of MARS.

- Factor 3 consisted of item number 9 corresponded to the antipsychotic side effects subscale in the original version of MARS.

- Factor 4 consisted of item number 10 which corresponded to the attitude toward antipsychotic treatment subscale in the original version of MARS.

\section{Discussion}

The validity and reliability test of the MARS Indonesian version in psychotic patient showed a valid and reliable result. The study was conducted at the Cipto Mangunkusumo Hospital (RSCM) Jakarta Psychiatric Outpatient Unit, taking into account that RSCM is a national referral hospital that receives patients from all economical levels and educational background. It is considered to be representative of the clinical population and can be applicable to similar settings.

The MARS instrument is an instrument composed of 10 questions that can be used to assess medication adherence in patients with psychosis (World Health Organization, 2016). In the process of translating the MARS instrument into Indonesian, there was one question that the community finds difficult to be understood by Indonesian in general, that is question number 9. The result of the initial translation of question number 9 reads "I feel strange, like the zombie, when taking medicine." This statement was considered confusing because the majority of Indonesians are not familiar with the words "zombie." The discussion then agreed to replace the words "zombie" with "robot." The results of the discussion were then confirmed to the original authors of the MARS instruments, namely Kathrine Thompson, Jayashri Kulkarni, Alex A. Sergejew of the University of Melbourne and they approved the adaptation (Thompson, et al., 2000).

This study was conducted in as many as 100 people with abnormal distribution. The internal consistency reliability test in this study showed the Cronbach's Alpha of 0.8 , while the retest test showed internal consistency value of 0.798. Meanwhile, Cronbach's Alpha values for the instrument subscale show values in the range 0.74 to 0.81 . This indicates that the MARS Indonesian version had a good internal consistency. The results of this study did not vary much with the results of original version of MARS instrument by Kathrine et al that reported Cronbach's Alpha value of 0.75 . Validity and reliability tests are also conducted in several other countries, like Australia and France. The tests conducted by Zemmour et al. in France used a sample of 319 people consisting of 53 women and 266 men with sampling location in homes for schizophrenic patients. As for data analysis, they were using software PASW 17.0.2 and MPLUS 7.2.2 (Zemmour et al., 2016). Unlike research conducted in Indonesia, the study by Zemmour et al used the Richard Formula-20 coefficient to determine the reliability value of the instrument, and found a reliability coefficient of 0.7 . Research using 66 research subjects consisting of 51 women and 15 men was performed in outpatient clinics in Australia. The validity test used in Thompson et al.'s research is multimethod matrix (Thompson, et al., 2000). The reliability test in that study used Cronbach's Alpha (internal consistency) and the test-retest method with Cronbach's alpha 
at 0.75 , this is not much different from the research done in Indonesia with Chronbach's alpha score 0.8.1 There are similarities of method and characteristics between current study and study by Kathrine et al, such as location of sampling at outpatient clinics, inclusion criteria of respondents with psychosis, average age of respondents 37.6 years $(\mathrm{SD}=11.09$ years) and data analysis using multitrait multimethod matrix.

The content validity test gave the results of content validity coefficient of 0.9 . These results suggest that the MARS Indonesian version is relevant in assessing adherence to drug consumption in psychotic patients. Two experts have only a difference of relevance, i.e. the statement number 6 where expert 1 gives a good rating (score $=3$ ) while expert 2 gives a bad rating (score $=2$ ). The statement reads "Unnatural for my mind and body to be controlled by drugs." However, since there is no significant difference (different 1 score between the assessment of the two experts), statement number 6 is retained in the final version.

The construction validity test using factor analysis method, it is found that the MARS Indonesian version composed of four factors: attitude towards treatment, behavior towards medication, antipsychotic side effect, and attitude towards antipsychotic treatment. These four factors are consistent with the results of initial research conducted by Thompson et al. (Thompson, et al., 2000).

Strengths in this study are that the researchers received training by mental health experts to make the diagnosis psychosis using SCID. The strength of the MARS Indonesian version has been tested for content validity, testretest reliability and factor analysis to assess the internal consistency of the instrument after a retest within two weeks after the first test with good test results. The weakness of this research is that the sampling is randomly selected. The weakness of this instrument is that there is no comparable instrument for drug compliance assessment in Indonesia that has been validated. Moreover, the questionnaire is a self-rated form which can overestimate compliance by $30 \%$ (Thompson, et al., 2000).

\section{Conclusion}

The MARS Indonesian version has been tested for validity and reliability, question items tailored to the culture of Indonesia. The results of validity and reliability test of the instrument are at a good level and repeated tests produced consistent results. The medication compliance assessment instrument in an Indonesian version for psychotic patients may be used as a baseline screening routine to find out medication adherence in psychotic patients by assessing factors including attitude towards treatment, behavior towards medication, antipsychotic side effect, and attitude towards antipsychotic treatment to increase treatment outcomes.

\section{References}

American Psychiatric Association, 2005, Diagnostic and Statistical Manual of Mental Disorder DSM IV (US: Washington DC), pp. 463-468.

Azwar, S., 2012, Reliabilitas dan Validitas. Vol. 4th Edition. Yogyakarta.

Babiker, I.E., 1986, Noncompliance in schizophrenia. Psychiatr Dev, 4(4), 329-37.

Badan Penelitian dan Pengembangan Kesehatan Kementerian Kesehatan RI, 2013, Riset Kesehatan Dasar.

Busner, J., Targum, S.D., 2007, The Clinical Global Impressions Scale. Psychiatry Edgmont, 4(7), 28-37.

Cohen, R., Swerdlik, M., 2005, Psychological testing and assessment: an introduction to test and measurement ( New York: McGraw-Hill).

Direktorat Jenderal Kesehatan RI, 2011, Standar Antropometri (Jakarta:Kementerian Kesehatan RI).

Erwina, I., 2011, Faktor-Faktor yang berhubungan dengan kepatuhan minum obat pasien Skizofrenia di RSJ. Prof. Dr. Hb. Saanin Padang (Padang: Universitas Andalas).

Fond, G., Boyer, L., Boucekine, M., Aden, L.A., Schürhoff, F., Tessier, A., et al., 2016, Validation study of the Medication Adherence Rating Scale. Results from the FACE-SZ national dataset. Schizophr Res. 
Gregory, R., 2007, Psychological testing: History, principles, and applications, Vol. Fifth Edition (New York: Pearson).

Hogan, T.P., Awad, A.G., Eastwood, R., 1983, A self-report scale predictive of drug compliance in schizophrenics: reliability and discriminative validity. Psychol Med, 13(1), 177-83.

Jaeger, S., Pfiffner, C., Weiser, P., Kilian, R., Becker, T., Längle, G., et al., 2012, Adherence styles of schizophrenia patients identified by a latent class analysis of the Medication Adherence Rating Scale (MARS): a six-month follow-up study. Psychiatry Res, 200(2-3), 83-8.

Jin, J., Sklar, G.E., Min Sen Oh, V., Chuen, L.S., 2008, Factors affecting therapeutic compliance: A review from the patient's perspective. Ther Clin Risk Manag, 4(1), 269-86. Kane, J., Kishimoto, T., 2013, Non-adherence to medication in patients with psychotic disorders: epidemiology, contributing factors and management strategies. World J Psychiatry.

Joyce, A., Cramer, B., Anuja, R., 2011, Medication Compliance and Persistence: Terminology and Definitions. Yale Univ Sch Med, 11.

Kemp, R., Hayward, P., Applewhaite, G., Everitt, B., David, A., 1996, Compliance therapy in psychotic patients: randomised controlled trial. BMJ, 312(7027), 345-9.

Lacro, J.P., Dunn, L.B., Dolder, C.R., Leckband, S.G., Jeste, D.V., 2002, Prevalence of and risk factors for medication nonadherence in patients with schizophrenia: a comprehensive review of recent literature. J Clin Psychiatry, 63(10), 892-909.

Magura, S., Mateu, P.F., Rosenblum, A., Matusow, H., Fong, C., 2014, Risk factors for medication nonadherence among psychiatric patients with substance misuse histories. Ment Health Subst Use Dual Diagn, 7(4), 381-90.

Maldiyono, Sastroasmoro, S., Budiman, I., 2002, Dasar-dasar Metodologi Penelitian Klinis (Jakarta: CV Sagung Seto), pp. 259-286.

Michael, B., Robert, L., Gibbon, M., 2002. Structured Clinical Interview for DSM-IV-TR Axis I Disorders. Biom Res.

NIMH, Schizophrenia, Date of 23/10/2016. https://www.nimh.nih.gov/health/publications/schizophrenia-booklet-12- 2015/index.shtml

Rössler, W., Salize, H.J., van Os, J., Riecher-Rössler, A., 2005, Size of burden of schizophrenia and psychotic disorders. J Eur Coll Neuropsychopharmacol, 15(4), 399-409.

Sadock, B. J., Sadock, V.A., Kaplan \& Sadock's comprehensive textbook of psychiatry, Date of Access: 30/09/2016.

http://www.worldcat.org/title/kaplan-sadocks-comprehensive-textbook-of- psychiatry/oclc/297801787

Saenz, D., Marinelli, R., 2011, A retrospective study of the correlation between diagnosis of schizophrenia or bipolar disorder and medication noncompliance. W Va Univ.

Samalin, L., Blanc, O., Llorca, P-M., 2010, Optimizing treatment of schizophrenia to minimize relapse. Expert Rev Neurother, 10(2), 147-50.

Sugiyono, 2006, Statistik Untuk Pengujian Validitas Dan Reliabilitas Instrumen Penelitian. Statistika untuk penelitian. pp. 267-284.

Suryabrata, S., 2005, Pengembangan alat ukur psikologis (Yogyakarta: Andi).

Thompson, K., Kulkarni, J., Sergejew, A.A., 2000, Reliability and validity of a new Medication Adherence Rating Scale (MARS) for the psychoses. Schizophr Res, 42(3), 241-7.

Thornley, B., Adams, C., 1998, Content and quality of 2000 controlled trials in schizophrenia over 50 years. BMJ, 317(7167), 1181-4.Toll, B.A., McKee, S.A., Martin, D.J., Jatlow, P., O’Malley, S.S., 2007, Factor structure and validity of the Medication Adherence Questionnaire (MAQ) with cigarette smokers trying to quit. J Soc Res Nicotine Tob, 9(5), 597-605.

Wardani, I., 2009, Pengalaman keluarga menghadapi ketidakpatuhan anggota keluarga dengan skizofrenia dalam mengikuti regimen terapeutik (Depok: Universitas Indonesia).World Health Organization, Global Health Estimates Date of Access: 31/10/2016. http://www.who.int/healthinfo/global_burden_disease/en/

World Health Organization, Schizophrenia, Date of Access: 30/09/2016. http://www.who.int/mediacentre/factsheets/fs397/en/

World Health Organization, 2011, Schizophrenia and public health (Geneva: World Health Organization). 
Zemmour, K., Tinland, A., Boucekine, M., Girard, V., Loubière, S., Resseguier, N., et al., 2016, Validation of the Medication Adherence Rating Scale in homeless patients with schizophrenia: Results from the French Housing First experience. Sci Rep, 6, 31598.

Zygmunt, A., Olfson, M., Boyer, C.A., Mechanic, D., 2002, Interventions to improve medication adherence in schizophrenia. Am J Psychiatry, 159(10), 1653- 64. 